\title{
Charity a diakonie - poskytovatelé sociálních služeb nebo sekundární církevní struktura? Michal Opatrný
}

Benedikt XVI. ve své slavné nástupní encyklice Deus caritas est uvedl, že se v historii „... s narůstajícím rozšiřováním církve ukázalo, že jednou z hlavních oblastí činnosti církve, spolu s udělováním svátostí a zvěstováním slova, je uplatňování lásky (caritas)... Církev nesmí opomíjet službu lásky (caritas), stejně jako nesmí opomíjet vysluhování svátostí a službu slova."1 Tento charitativní úkol je veskrze katolický - všeobecný, protože se netýká jen katolické církve, jakoby šlo o úkol stanovený papežem, nýbrž celého křestanstva - a to z jeho samotné podstaty. V těchto intencích také uvažuje Benedikt XVI. v encyklice Deus caritas est, když charitativní úkol křestanství zdůrazňuje. Jeho kořeny můžeme najít již v knize Skutků apoštolských, kde je praktická dobročinnost chápána jako jeden z klíčových znaků nově vznikající církve (Sk 2, 45-46).

Charitativní úkol je dnes naplňován např́ič křest’anskými církvemi a konfesemi především skrze pomáhající organizace, které zakládají jak př́ímo různé církve nebo konfese, tak i místní církve, řehole nebo místní křestanské komunity jako farnosti, sbory nebo církevní obce anebo vznikají jako sdružení věřících apod. ${ }^{2}$ Tyto organizace jsou v evropském prostředí zpravidla akreditovány jako poskytovatelé sociálních služeb, ${ }^{3}$ kteří na poskytování těchto služeb čerpají veřejné prostředky od státu, samosprávných celků a obcí i od nadací a dárců mimo církev. $\mathrm{V}$ některých případech jsou spolufinancováni také z církevních prostředků. Tento stav se postupně rozvíjí od počátku 20. stol., kdy začaly vznikat konfesní pomáhající organizace přibližně dnešního ražení. ${ }^{4}$ Církve plní svůj charitativní úkol samozřejmě i jinak, napřr. skrze nemocniční kaplanství, apod. Pomáhající organizace založené církvemi, jako jsou v České republice např. Charita ČR, Diakonie ČCE apod., jsou však dominantní a to nejen v církevním prostředí, ale i mezi pomáhajícími organizacemi obecně. Proto zejména v církevním prostředí vyvstává otázka, zda tyto organizace ještě fungují jako součást církve, jsou přímou součástí její struktury, nebo se už staly běžnými poskytovateli sociálních služeb, fungují jako mnohé jiné organizace, a vazba na církev spočívá jen v jejich založení církví a specifickém pojmenování (např. Charita, Diakonie, Hospic sv. Veroniky, atp.). Někteří autoři proto v této souvislosti hovoří o tzv. podvojné nebo rozdvojené struktuře církve - jednou strukturou jsou farnosti, sbory nebo církevní obce, druhou charity, resp. v případě jiných konfesí jiná organizace nebo sít organizací. Někdy

Deus caritas est 22

V katolickém prostředí srov. CIC 1984 kán. 215.

V ČR např. dle zák. 108/2006 Sb.

Srov. Catherine MAURER, Wie entstand die „Caritaswissenschaft“?: Ursprung und Entwicklung eines Konzepts und einer Handlungspraxis, in: Die ersten hundert Jahre: Forschungsstand zur Caritas-Geschichte, ed. Michael MANDERSCHEID - Hans-Josef WOLLASCH, Freiburg i. Br.: Lambertus, 1998, s. 144. 
je tato struktura nazývána také druhotnou či sekundární. ${ }^{5}$

Proto nepřekvapuje, že se již během 20. stol. objevila např. v katolickém diskurzu celá řada více či méně komplexních koncepcí z oblasti praktické teologie a teorie charity (Caritaswissenschaft), které chtěly rozdvojenou církevní strukturu znovu scelit. V zásadě měly vždy dvojí podobu. Bud' usilovaly o nalezení způsobu, jak diakonizovat církev - zapojit farnosti do činnosti Charity či dát ve farní pastoraci větší důraz na diakonii, nebo jak zpětně pocírkevnit charitu - navrátit do církve a obrátit pracovníky Charity ke křestanské víře. ${ }^{6}$ Podle některých autorů, jako je např. Hermann Steinkamp, jsou ale největší překážkou pro znovusjednocení církevní struktury především samy pomáhající organizace zřizované církvemi, protože na ně mohou křestané svůj charitativní úkol delegovat a v jistém smyslu tak udržovat při životě rozdvojenou strukturu. ${ }^{7} \mathrm{~V}$ zásadě by proto podle této koncepce bylo nejlepší, pokud by charitativní úkol realizovaly přímo farnosti a církevní pomáhající organizace vůbec neexistovaly. ${ }^{8}$

V dnešní situaci se však nezdá být reálné, aby se tyto organizace prostě zrušily nebo osamostatnily a vyvázaly z církevního zřízení. Křestané by tak rezignovali na profesionální přístupy k lidské nouzi prostřednictvím sociální práce a dalších pomáhajících profesí. Šlo by tedy o velmi fatální řešení. Obráceně se jeví jako problém pouhá diakonizace farní pastorace, ${ }^{9}$ resp. diakonizace církví při zachování nezávislého provozu církevních pomáhajících organizací. Vedle rizik spojených s rozvojem pomáhajících činností bez odpovídající rozumové reflexe ${ }^{10}-$ tj. bez znalostí a dovedností z oboru sociální práce, bez supervize a kontroly kvality, která je obvyklá v sektoru sociálních služeb - by tento přístup vyžadoval rovněž komplexní změny myšlení v církvích i změny v jejich strukturách. ${ }^{11}$ Je tedy nutné hledat řešení, které zahrne jak pomáhající organizace, tak i samotnou církev. Restriktivně lze záměr tohoto řešení formulovat tak, že by pomáhající organizace neměly tlakem na profesionalizaci „kanibalizovat“ realizaci charitativního úkolu církví ve farnostech, sborech a církevních obcích; pastorační struktura (tzn. farnosti, sbory nebo církevní obce) by se pak neměla omezovat pouze na bohoslužby, výuku náboženství a misijní působení. Záměr řešení, které by zahrnulo jak pomáhající organizace, tak i pastorační struktury církví, může být ale formulován i podpůrně. Pomáhající organizace by podle tohoto pojetí řešení měla podporovat charitativní úkol církve v rámci její pastorační struktury a ta by opačně měla podporovat organizaci v její činnosti, aby jí tak umožnila nebýt pouhým poskytovatelem sociálních služeb, ale organizací realizující především charitativní úkol církve.

Tato studie se chce proto věnovat právě tomuto podpůrnému pojetí vztahu charitativní a pastorální struktury církví. Jejím prvotním záměrem je především analýza a kritické posouzení výše popsané situace podvojné struktury církví z hlediska teologie. ${ }^{12}$ Návrhy řešení pro praxi chce

5 Srov. Jakub DOLEŽEL, Teoretické ukotvení církevní sociální práce na pozadí obecných a českých charitních dějin až po encykliku Deus caritas est (disertační práce, školitel Heinrich Pompey), Olomouc: CMTF UP, 2011, s. 74; Herbert HASLINGER, Diakonie: Grundlagen für die soziale Arbeit der Kirche, Paderborn - München - Wien - Zürich: Schöningh, 2009, s. 47. Dále srov. Klaus BAUMANN, Unverzichtbar - die Soziale Arbeit der Kirche, Sozialmagazin 12/2007, s. 31; srov. Hermann STEINKAMP, „Zweitstruktur“ - Diakonie oder diakonische Kirche, in: Den Himmel offen halten: Ein Plädoyer für Kirchenentwicklung in Europa, ed. Isidor BAUMGARTNER Christian FRIESL - András MÁTÉ-TÓTH, Innsbruck - Wien: Tyrolia, 2000, s. 71-72; Heinrich POMPEY - Paul-Stefan ROSS, Kirche für andere: Handbuch für eine diakonische Praxis, Mainz: Grünewald, 1998, s. 141.

6 Srov. Michal OPATRNÝ - Tereza MORONGOVÁ, Outsourcing bliženecké lásky, Studia theologica 18/2016, s. 111-124.

7 Srov. Hermann STEINKAMP, „Zweitstruktur“ - Diakonie oder diakonische Kirche, s. 71-91.

8 Srov. Hermann STEINKAMP, Sozialpastoral, Freiburg i. Br.: Lambertus, 1991, 158 s.

9 Na TF JU je v současnosti na téma farní charity (nikoliv pouze farních charit coby součástí diecézní charity) realizován disertační projekt, který se po předběžném šetření v pastorační praxi musí vyrovnat se zásadní obtíží, že charitativní angažmá farností v ČR prakticky neexistuje. Řešitelkou projektu je Monika Flídrová.

10 Srov. Silvia STAUB-BERNASCONI, Soziale Arbeit als Handlungswissenschaft, Bern - Stuttgart - Wien: Haupt, 2007 , s. 12.

11 Srov. Michal OPATRNÝ - Tereza MORONGOVÁ, Outsourcing blíženecké lásky, s. 123-124.

12 Srov. Herbert HASLINGER a kol., Zu Selbstverständniss und Konzept dieser Praktischen Theologie, in: Handbuch Praktische Theologie: Grundlegungen, ed. Herbert HASLINGER, Mainz: Grünewald, 1999, s. 31-32. 
podat jen v minimální nutné míře, protože ochota ke změně stávající praxe je do značné míry podmíněna přijetím analýzy této praxe coby praxe nedostatečné.

\section{Vznik a rozvoj podvojné struktury}

Již před lety představil Mette svou interpretaci dějin charitativní a diakonické činnosti křestanů, kterou se pokusil vysvětlit zejména stav dnešní struktury církve rozdvojené, např. v katolickém prostředí mezi farnosti a Charitu. ${ }^{13}$ Jeho prvopočátky spatřuje již ve 2 . stol. po Kr., kdy bylo možné konstatovat určitou rivalitu mezi kněžími (presbytery) a jáhny (diákony). Jejím důsledkem byla redukce jáhenství na př́pravný předstupeň kněžství. $S$ tím však byla spojena ztráta instituční odpovědnosti za charitativní úkol církve. Postupně proto zmizelo i vědomí o „všeobecném jáhenství věřících“, tzn. zároveň i o významu charitativního úkolu církve. $V$ dalších staletích postupně rostoucí význam kultického rozměru bohoslužby, který souvisel se zdůrazňováním kněžského úřadu, podmínil souběžné znehodnocení sociální dimenze bohoslužby a nakonec vedl k situaci, kterou Mette označil za sociální dezintegraci kultu. S tím byla spojená tendence k oddělení církevní obce a charity do té míry, že charita stále více přecházela do působnosti rádů a společenství zřizovaných pro tento účel. Sice stále znovu vznikaly iniciativy, které reagovaly „odspodu“ na situační proměny nouze ve společnosti, byly však bud” „,vyvlastněny“ prostřednictvím tlaků na jejich (úředně-)církevní uznání, nebo byly donuceny takříkajíc odejít do „sekularizace“. ${ }^{14}$

V komplexní moderní společnosti je tak podle Metteho diferencovaná organizační forma Charity jako neziskové organizace akreditované coby poskytovatel sociálních služeb nakonec nevyhnutelná. V důsledku toho ale Charitu dále provází „ztráta společenství (koinonie)“- diakonie není věcí společenství křestanů; společenství křestanů není za křestanskou diakonii zodpovědné. Charita se tak podle Metteho stala pro křestanské jednání konsekutivní (druhořadou) a nikoliv konstitutivní. ${ }^{15}$ Jak již bylo zmíněno, během 20. stol., kdy se moderní charitativní organizace církví konstituovaly, byla učiněna celá řada pokusů, jak výše popsanou propast mezi komunitou křestanů - koinónií a jejich charitativním úkolem - diakonií překonat. Prakticky všechny tyto pokusy více či méně ztroskotaly nebo nikdy skutečně nevstoupily v život. ${ }^{16}$

Výrazným impulsem pro znovunastolení této problematiky bylo v r. 2013 zvolení kardinála Jorge Mario Bergoglio za papeže. Přijetím jména František dal svému pontifikátu do značné míry charitativní rozměr. ${ }^{17}$ Jakkoliv není postava Františka z Assisi v katolické hagiografii spojována s dobročinností nebo charitou mezi prvními, jméno velmi dobře vystihuje záměr Františkova pontifikátu, že pro křestanství je konstitutivní takové pojetí skromnosti, které vychází z ohledu na druhé a celek stvoření. ${ }^{18}$ Právě konstitutivní souvislost mezi vírou a způsobem života, resp. propojení

13 Srov. Norbert METTE, Theologie der Caritas, in: Grundkurs Caritas, ed. Markus LEHNER - Wilhelm ZAUNER, Linz: Landesverlag, 1993, s. $125-127$.

14 Sheldrake v této souvislosti hovoří např. o hnutí bekyň, ale také o samotném Tovaryšstvu Ježíšovu (srov. Philip SHELDRAKE, Spiritualita a historie: Úvod do studia dějin a interpretace křestanského duchovního života, Brno: CDK, 2003, zejména s. 132-155, př́p. s. 129-131).

15 Srov. Norbert METTE, Theologie der Caritas, s. 126.

16 Srov. Michael MANDERSCHEID - Hannes KRAMER, Programatik und Praxis von Gemeindeorientierung des Caritasverbandes Erfahrung und Aporie, in: Zwischen versorgter Gemeinde und entsorgender Sozialarbeit: Dokumentation des Symposions "Christliche Diakonie zwischen System und Lebenswelten"von 13. bis 15. März 1989, ed. Michael MANDERSCHEID, Freiburg i. Br.: DCV, 1990, s. 8-11.

17 Srov. Paul M. ZULEHNER, Kirchenentwicklung braucht Visionen: Papst Franziskus liefert uns solche, in: Papst Franziskus: Ermutigung und Herausforderung für Theologie und Pastoral in Mittel- und Osteuropa, Pastoraltheologische Hefte 8 (2015): Eine Veröffentlichung des Post-Netzwerkes der mittel- und osteuropäischen Pastoraltheologinnen und Pastoraltheologen, ed. Mieczysław POLAK, Gniezno - Wien: Gaudentinum, 2015, s. 13.

18 Srov. Wiesław PRZYGODA, Armut als Pastorales Prinzip nach Papst Franziskus, in: Papst Franziskus: Ermutigung und Herausforderung für Theologie und Pastoral in Mittel- und Osteuropa, Pastoraltheologische Hefte 8 (2015): Eine Veröffentlichung des Post-Netzwerkes der mittelund osteuropäischen Pastoraltheologinnen und Pastoraltheologen, ed. Mieczysław POLAK, Gniezno - Wien: Gaudentinum, 2015, s. 59-63. 
obsahu víry s dobročinností, ${ }^{19}$ které je někdy vyjadřováno heslem „chudá církev - církev pro chudé ${ }^{\text {“20 }}$, je i novým impulsem pro sjednocení rozdvojené církevní struktury. Pokud totiž vztah mezi obsahem křestanské víry a praktickou dobročinností nebude považován za vzájemně konstitutivní, jen těžko bude moci rozdvojenou strukturu církve znovu sjednotit. Pastorální struktura, která obsah víry vyjadřuje explicitně za pomocí slov a symbolického jednání, nebude Charitu potřebovat tak jako doposud. ${ }^{21}$ Charita v organizované podobě pomáhající organizace poskytující sociální služby se pak zase bude i nadále orientovat především na takové sociální služby, které jsou ze strany sociálního státu dobře zaplacené; a méně či vůbec na takové činnosti, které by důsledně realizovaly křestanský charitativní úkol. ${ }^{22}$

\section{Mentalita podvojné struktury}

Podvojná struktura však již byla jak církví, tak i Charitou takříkajíc přijata za vlastní. Požadované změně tudíž $\mathrm{v}$ cestě nestojí ani tak samotné pomáhající organizace, nebo samotná církev, jako představa, že zdvojená struktura je vlastně normální - tzn. mentalita podvojné struktury. To má zcela praktické důsledky:

- Z pohledu klientů, donátorů, státních, krajských a obecních úředníků a někdy i jejích pracovníků je Charita běžně vnímána jako jakýkoliv jiný poskytovatel sociálních služeb. Pokud jsou si jejího církevního původu vůbec vědomi, vnímají ji jako jakousi „dceřinou firmu“ církve - jako organizaci, která je církví zřizována, která je s ní nějakým způsobem personálně a právně propojená, která ale není na první ani druhý pohled s církví totožná: sídlí v jiných budovách a lidé se s ní setkávají v jiném kontextu, než v jakém se setkávají s církví.

- Představitelé církví, vedení Charity a někteří z jejích pracovníků, dobrovolníků či klientů, kteří jsou v církvi socializováni, naopak vnímají především teologickou jednotu Charity a církve - že organizace naplňuje výše zmíněný charitativní úkol, který podle Benedikta XVI. církev nesmí opomíjet.

Tato dvě pochopení Charity mohou být nakonec tak dalece odlišná, že způsobují hluboká neporozumění a závažné konflikty. Stručně vyjádřeno, „... zatímco vnější pozorovatel popisuje situaci, jaká je, katolická církev popisuje identitu (Charity, pozn. aut.), jaká by měla být. “23 Druhý pohled však zcela přehlíží skutečnost, že se pak části církve činnost Charity vůbec netýká. Je to vlastně logické, protože v tomto pojetí se jí ani týkat nemusí. Můžeme proto také říci, že empiricky (tj. na základě rozpoznatelných faktů) je Charita vnímána jako poskytoval sociálních služeb s křestanským zřizovatelem, zatímco teologicky - a jedině a pouze teologicky - i jako součást církve, která plní její dưležitý úkol.

Napětím mezi pojmy empiricky a teologicky se také popisují a vysvětlují různé typy pojetí církve a jejího vztahu ke světu, resp. ke společnosti:

19 Srov. Josip BALOBAN, Papst Franziskus und die müden europäischen Verkündiger und Christen, in: Papst Franziskus: Ermutigung und Herausforderung für Theologie und Pastoral in Mittel- und Osteuropa, Pastoraltheologische Hefte 8 (2015): Eine Veröffentlichung des Post-Netzwerkes der mittel- und osteuropäischen Pastoraltheologinnen und Pastoraltheologen, ed. Mieczysław POLAK, Gniezno - Wien: Gaudentinum, 2015, s. 29-30.

20 Evangelii gaudium 198.

21 Srov. Jakub DOLEŽEL, Farní charity: dozvuky encykliky Deus caritas est a pravděpodobný stav moravských farností, Studia theologica 3/2016, s. 147-166.

22 Srov. Michal OPATRNÝ - Tereza MORONGOVÁ, Outsourcing blíženecké lásky, s. 111-124.

23 Srov. Petr KOLAŘÍK, Identita sociálních služeb poskytovaných katolickou církví, Sociální práce / Sociálna práca 4/2008, s. 76 a 82. 
- První typ se vyznačuje ztotožňováním empirické a teologické skutečnosti církve, což znamená, že to, co o církvi ř́ká teologie, resp. eklesiologie, je chápáno jako popis stávající podoby empirické církve. ${ }^{24}$

- Ve druhém typu jsou naopak teologická a empirická skutečnost církve striktně oddělovány. Nejen nekřestané a matrikoví věřící, ale i řada praktikujících laiků chápe církev jako jednu z mnoha dalších specializovaných institucí, resp. jako instituci specializovanou na uspokojování náboženských potřeb. Teologický význam slova církev, resp. Boží lid, tělo Kristovo atd. vnímají jen ti, kdo jsou ustanoveni k pastoraci, resp. absolvovali teologické studium, a několik málo aktivních věřících laiků vzdělaných v obsahu víry.

- Třetím typem, který autor tohoto rozlišení Medard Kehl ukazuje jako jediný opodstatněný, je pak jednota obou skutečností na způsob svátosti. To je také pohled II. vatikánského koncilu, resp. prvního článku jeho věroučné konstituce o církvi Lumen gentium: „... nebot vnější viditelná podoba církve má být znamení, symbol a svátost, prostředek a nástroj vnitřního tajemství církve. " 25 Vztáhneme-li tento třetí typ také k napětí mezi empirickým a teologických chápáním Charity, nesmíme si položit pouze otázku, jakým způsobem je třeba změnit vnější - empirickou podobu Charity tak, aby vyjadřovala i její teologické pojetí, ale také, jaká je církev, její vnitřní uspořádání a zaměrení, a zda tedy má Charita v církvi na co odkazovat.

Skutečnost, že jsou charity vnímány jako prostí poskytovatelé sociálních služeb a to nejen veřejností, ale také uvnitř církve samotné, je totiž příznak toho, jak malá pozornost je v církvi věnována sociálním tématům a problémům. Jinak vyjádřeno, že církevní struktura není jen rozdvojená nebo podvojná, ale především rozdělená na primární pastorální strukturu a sekundární - podružnou charitní strukturu.

\section{Konkluze}

Chceme-li tedy dojít k hledání podpưrného pojetí spolupráce mezi zřizující církví a její pastorální strukturou s pomáhající organizací při realizaci charitativního úkolu křestanství, je třeba v první řadě vrátit charitativnímu úkolu křestanů jeho pravou hodnotu. Jak bylo zmíněno v úvodu a v bodě $1, \mathrm{v}$ katolickém kontextu je právě toto jedním ze záměrů pontifikátu současného římského biskupa Františka, byt’ toto téma již otevřel jeho předchůdce Benedikt XVI. S tím je spojena otázka propria křestanské charity, tedy otázka, jaké priority by mělo plnění charitativního úkolu sledovat. Zdá se totiž, že charitativní úkol byl do značné míry difamován tím, že se rozptýlil do na první pohled nekonečného množství dobročinných aktivit, které křestanské pomáhající organizace uskutečňují. Takto pojatá dobročinnost se posléze nijak výrazně neliší od jiných dobročinných aktivit, resp. jakékoliv rozdíly a odlišné priority se stávají nečitelnými. Tradičním a biblicky nejen podloženým, ale zejména opodstatněným propriem charity je pomoc těm, kterým ostatní nepomáhají. Je to jednoznačný závěr, který vyplývá z podobenství o milosrdném Samaritánovi, kde se bližním stává heretik a schizmatik, který neváhal pomoci tomu, kterého ostatní obešli. Jak vysvětluje celé podobenství spolu se svým kontextem, právě ten, kdo je pro druhé bližním, koná také to, co je důležité pro spásu. ${ }^{26}$

24 S tímto pojetím se můžeme setkat např. ve starších příručkách, podle kterých byla v Česku vyučována eklesiologie až do 90 . let 20 . stol. Důsledkem tohoto pohledu je tak fatální omyl zaměňující pojmy církev a Boží království jako totožné. Srov. Vojtěch NOVOTNÝ, Česká katolická eklesiologie na počátku druhé poloviny 20. století, in: Česká katolická eklesiologie druhé poloviny 20. století, ed. Vojtěch NOVOTNÝ, Praha: Karolinum, 2007, s. 9-46.

25 Srov. Medard KEHL, Kam kráčí církev: Diagnóza doby, Brno: CDK, 2000, s. 45-51.

26 Srov. Michal OPATRNÝ, Podobenství o milosrdném Samaritánovi a proprium křestanské charitativní práce v kontextu tzv. teorie charity, Studia theologica 3/2016, s. 167-184. 
Církevní pomáhající organizace se však v současné době orientují právě na takové sociální služby, které jsou ze strany státu resp. politických regionů favorizované. ${ }^{27}$ Je tedy třeba, aby provedly změny ve svých prioritách a struktuře, které umožní věnovat se klientům, na které sociální systém státu i společnost jako celek nepamatuje nebo pamatuje jen málo a nesystémově. Tím se také samy stanou pro své zřizující církve lépe uchopitelné a čitelné. Taková změna přirozeně přinese finanční nestabilitu, protože se organizace již nebude moci (plně) spolehnout na podporu státu a jeho systému sociálních služeb. Pro realizaci a udržitelnost takové změny v orientaci své základní činnosti budou proto charity a diakonie potřebovat výraznou pomoc a podporu od svých církví. Taková podpora může být finanční (výnosy z restitucí, sbírky), materiální (úroda, sbírky) nebo i personální (dobrovolníci). Poskytnutí podpory takového rozsahu tedy nemůže být v silách výhradně církevního ústředí, ale bude třeba, aby ji přijaly za vlastní i konkrétní články pastorální struktury církve - farnosti, sbory nebo církevní obce. Charity a diakonie tím budou podporovat uskutečňování charitativního úkolu církve uvnitř její pastorální struktury a církve tak svým organizacím umožní, aby nebyly jen pouhými poskytovateli sociálních služeb.

27 Srov. Michal OPATRNÝ - Tereza MORONGOVÁ, Strukturálně-kritická sociální práce v církevním hávu: Contradictio in adjecto?, in: Sociální práce v nejisté době, ed. Ondřej ŠTĚCH - Peter PATYI - Zuzana TRUHLÁŘOVÁ, Hradec Králové: Gaudeamus, 2016, s. 38-41. 


\title{
Charity a diakonie - poskytovatelé sociálních služeb nebo sekundární církevní struktura?
}

\begin{abstract}
Abstrakt
Studie se zabývá vztahem mezi pomáhajícími organizacemi zřízenými církví a zřizující církví. Vychází z obecného charitativního úkolu křest’anů, který je v současné době uskutečňován právě církevními pomáhajícími organizacemi akreditovanými jako poskytovatelé sociálních služeb. Studie ukazuje, jak je díky této praxi charitativní úkol církví podvazován. Př́čina tohoto stavu je identifikována v odlišném vnímání organizací a jejich práce v církevním prostředí a ve světském prostředí. Světské sekulární prostředí nechápe charitativní organizace jako součást církve, která skrze ně realizuje svůj charitativní úkol, ale spíše jako dceřinou firmu církve. V důsledku je pak v církevním prostředí práce organizací vnímána jako práce běžného poskytovatele sociálních služeb a tím je vyvolána otázka, zda jsou vůbec ještě křestanské. Studie proto navrhuje jako základní směr pro řešení vztahu pomáhajících organizací a zřizujících církví, aby organizace částečně rezignovaly na zapojení do systému sociálních služeb ve prospěch pomoci těm, na které systém sociálních služeb nepamatuje. Pro to ale potřebují výraznou materiální i morální podporu ze strany církví. Pokud by jim jí církve poskytly, byla by tím zároveň přenesena odpovědnost za realizaci charitativního úkolu do jejich základní struktury.
\end{abstract}

Klíčová slova: caritas, diakonie, charita, církev, křest’anská sociální práce, sociální práce, eklesiologie

\section{Kontakt na autora}

\section{doc. Michal Opatrný, Dr. theol.}

Jihočeská univerzita v Českých Budějovicích

Teologická fakulta, Katedra etiky, psychologie a charitativní práce

Kněžská 8, 37001 České Budějovice

mopatrny@tf.jcu.cz 